\title{
REGELGEVING TEN AANZIEN VAN \\ NIET-FINANCIËLE INFORMATIE
}

\author{
door Dr. H. Schreuder
}

\section{Afbakening van het onderwerp}

Deze bijdrage zou zich volgens de omschrijving van de redaktie dienen te rich. ten op de „niet-financiële informatie” in het kader van de voorschriften voor de jaarrekening. Bij een strikte interpretatie van deze omschrijving zou met een zeer summiere bijdrage kunnen worden volstaan. De jaarrekening is im. mers bij uitstek het instrument voor juist de financiële informatieverstrekking en verantwoording, zodat volgehouden kan worden dat niet-financiële infor. matie hierin per definitie geen plaats heeft.

Een dergelijke strikte interpretatie zou bij sommigen twijfels kunnen oproe pen. Een gedeelte van de in jaarrekeningen verstrekte informatie luidt immers niet in financiële termen. Zou die informatie dan toch niet in beschouwing moeten worden genomen? Deze overweging wijst er al op dat de afbakening van ons onderwerp ten sterkste bepaald wordt door de inhoud die gegeven wordt aan de term „financieel”. Daarbij kan primair worden gelet op het doel van de informatieverstrekking (bijv. het afleggen van financiële verantwoor. ding) of op de vorm van de informatie (al dan niet in financiële termen). Hier zal onder ,niet-financiële informatie" worden verstaan: informatie die (a) bui. ten de jaarrekening wordt verstrekt en (b) niet luidt in financiële termen. Deze bijdrage valt derhalve in zoverre buiten het door de redaktie aangegeven ka. der dat de aandacht niet gericht is op de jaarrekening. De voorschriften ten aanzien van niet-financiële informatie zijn echter juist buiten dit kader interes. sant.

Een volgend afgrenzingsprobleem doet zich voor ten aanzien van de wijze van informatieverstrekking. Hier bestaan legio mogelijkheden door combinatie van elementen als (al of niet) schriftelijk, periodiek, openbaar, gereglemen teerd, ,general purpose” etc. De beste aansluiting bij de opzet van dit bijzonder nummer van het M.A.B. wordt waarschijnlijk verkregen door de aandacht te richten op de regelgeving ten aanzien van periodiek door ondernemingen te verstrekken schriftelijke informatie, die in het algemeen openbaar is. Hieronder valt zowel "general purpose" als „special purpose information”. Deze in formatie kan in het jaarverslag zijn vervat of in andere dragers van schriftelijke informatie.

De genoemde criteria sluiten vele informatiestromen uit, die in onderne mingsland waargenomen kunnen worden. Dat echter ook binnen het aldus afgebakende gebied sprake is van vele in aantal en omvang toenemende informatiestromen, en van een steeds uitgebreider reglementering, zal in het ver. volg worden toegelicht. In de volgende paragraaf wordt eerst op de achter. grond van dit verschijnsel ingegaan. Vervolgens komt de regelgeving door in. ternationale organisaties aan de orde. Over de nationale regels ten aanzien van niet-financiële informatie wordt in paragraaf 4 geconcludeerd dat deze te 
divers zijn om een integraal overzicht toe te staan. Derhalve wordt bij wijze van illustratie de situatie in de Verenigde Staten van Amerika geschetst. Over de Amerikaanse situatie zijn namelijk de laatste tijd onderzoekresultaten beschik. baar gekomen betreffende de effekten van zulke regelgeving. Deze worden in paragraaf 6 gepresenteerd. Dergelijke gegevens ontbreken voor de meeste andere landen. Mede gezien de uitkomsten van het Amerikaanse onderzoek wordt ons onderwerp afsluitend in een ruimer kader geplaatst. Daarbij komt de vraag centraal te staan welke alternatieven bestaan voor de regelgeving in het algemeen en de verplichtingen tot informatieverstrekking in het bijzonder.

\section{Vermaatschappelijking als achtergrond}

De informatieverstrekking door ondernemingen heeft de laatste jaren in een groot deel van de westerse wereld een sterke uitbreiding te zien gegeven. Daarbij is de toename van de niet-financiële informatie in het algemeen van recenter datum dan bij de financiële informatie het geval is. Als achtergrond van deze ontwikkeling kan de „vermaatschappelijking" van de onderneming worden gezien. Bouma en Van de Poel (1979, p. 347) omschrijven deze term als „de aanpassing van de organisatie aan de eisen, verwachtingen en waarden van de omgeving (externe participanten)". Deze aanpassing kan ook worden om. schreven als de externe vermaatschappelijking van de onderneming (vgl. Koopman, 1979). De afstemming van de organisatie op de doeleinden etc. van de interne participanten kan dan als interne vermaatschappelijking worden aangeduid. ')

Wat in de bovenstaande omschrijvingen nog niet expliciet tot uitdrukking komt, is dat in het vermaatschappelijkingsproces ook de kring van deelgenoten in de onderneming ruimer zal worden getrokken. Door zowel ontwikkelingen aan ondernemingskant (vooral de groei van individuele ondernemingen) als door maatschappelijke ontwikkelingen dienen zich nieuwe groepen deelgenoten aan, die deels als legitiem worden erkend. De onderneming heeft zich derhalve niet alleen in te stellen op veranderende opvattingen van bestaande groeperingen deelgenoten, maar ook op nieuwe "gerechtvaardigd betrokken groeperingen" (Brevoord, 1978). Zo kan - met Van Dijck (1975, p. 6) - de vermaatschappelijking van de onderneming worden gezien als een situatie van meer en ingrijpender effekten van ondernemingen op de samenleving, en van meer en ingrijpender eisen van de samenleving m.b.t. het funktioneren van de onderneming. Het is deze bron waaruit m.i. de druk tot verdergaande nietfinanciële informatieverstrekking voortkomt (vgl. Schreuder, 1980).

Deze druk neemt lang niet altijd de vorm aan van regelgeving. Opvallend is juist dat op dit gebied vrij veel onverplichte ondernemingsinitiatieven kunnen worden gesignaleerd. In ons land is bijvoorbeeld de opkomst van het sociaal jaarverslag niet toe te schrijven aan regelgeving dienaangaande. Eenzelfde situatie doet zich voor bij de experimenten met sociale en maatschappelijke

\footnotetext{
1) Bouma en Van de Poel (1979, p. 346) hanteren hiervoor de term „humanisering". Overigens is het onderscheid tussen interne en externe participanten problemarisch. Dit onderscheid wordt in Schreuder (1981) getrokken langs de lijnen van de deelname aan de besluitvorming. Tevens wordt onderscheiden tussen enerzijds participanten/deelnemers, van wie een aktieve bijdrage aan het funktioneren van ondernemingen wordt gevraagd, en anderzijds deelhebbers, die min of meer pas sief de effekten van ondememingsaktiviteiten ondergaan. Beide groepen behoren tot de dcelgenoten in de onderneming
} 
verslaggeving in het buitenland (zie Schreuder, 1980). Indien een dergelijke ontwikkeling zich doorzet - zoals in ons land t.a.v. de sociale verslaggeving het geval is - kan de regelgeving zich beperken tot codificering van een reeds goed. deels ingeburgerde praktijk. Een dergelijke, vrij massale ontwikkeling vormt echter een uitzondering. Vele van de hier te bespreken regels belichamen der. halve geen codificering, maar moeten worden opgevat als wensen tot modificering van de bestaande praktijk.

\section{Internationale organisaties}

Van de in het inleidend artikel genoemde, internationale organisaties hebben vooral de OESO en de VN zich beziggehouden met regelgeving op het terrein van de niet-financiële informatie. Beide hadden daarbij de multi- of transnationale ondernemingen op het oog. $\left.{ }^{2}\right)$ In de OESO-richtlijnen voor multinationale ondernemingen van 21 juni 1976 worden onder het hoofd ,openbaarmaking van gegevens" een negental onderwerpen opgesomd, waarover periodiek gegevens gepubliceerd dienen te worden. Als niet-financiële informatie kunnen worden opgevat de gegevens over (1) de struktuur van de onderneming, (2) de voornaamste aktiviteiten per geografisch gebied en (3) het gemid. delde aantal werknemers in elk geografisch gebied.

Ook schrijven de OESO-richtlijnen gegevensverschaffing aan de nationale overheden voor m.b.t. mededingingsvraagstukken en de belastingheffing, en aan vertegenwoordigers van de werknemers voor zinvolle onderhandelingen over de arbeidsvoorwaarden. De laatsten dienen ook, ,wanneer zulks overeenstemt met het plaatselijk recht of gebruik", gegevens te ontvangen waardoor zij zich een juist beeld kunnen vormen van de aktiviteiten en de bedrijfsresul. taten van de vestiging of, waar dienstig, van de onderneming. Over de wijze waarop deze gegevens moeten worden verschaft zijn geen nadere bepalingen opgenomen. In haar „verduidelijkingen” wijst de OESO Committee on Inter. national Investment and Multinational Enterprises er wel op dat het hoofdkan. toor ervoor moet zorgen dat de vestigingen voldoende en tijdig informatie ont. vangen om aan hun informatieverplichtingen volgens nationaal recht, praktijk en gedragscode te kunnen voldoen (Blanpain, 1980, pp. 28.29). In het kader van de OESO is overigens een Working Group on Accounting Standards in april 1980 aan het werk gegaan. Deze groep dient onder meer verdere verduide lijkingen van de in de richtlijnen gebruikte accounting-termen te bereiken.

De OESO-richtlijnen zijn niet bindend. Dat hebben zij gemeen met de „Tri partiete beginselverklaring betreffende multinationale ondernemingen en sociaal beleid" van de Internationale Arbeidsorganisatie. In artikel 54 van deze beginselverklaring komen dezelfde informatieplichten aan werknemers voor als in de OESO-richtlijnen. Eind 1980 werd bekend dat de Europese Commissie een richtlijn heeft uitgewerkt inzake het informeren en consulteren van werk. nemers. Een dergelijke richtlijn zou, na goedkeuring door de lidstaten, wel een bindend karakter krijgen. Zoals bekend, eist de vierde richtlijn reeds een ver-

\footnotetext{
Overigens was de Intemational Chamber of Commerce de eerste internationale organisatie die een gedragscode voor multinationale ondernemingen publiceerde in de vorm van de "Guidelines for international investment" (1972). De UNC. TAD schaarde zich voorlopig als laatsie in de rij met de "Set of multilaterally agreed equitable principles and rules for the control of restrictive business practices" (1980).
} 
melding van het gemiddelde personeelsbestand gedurende het boekjaar, ge splitst naar categorieën, alsmede de personeelskosten van het boekjaar. Ook moet in het jaarverslag worden ingegaan op de werkzaamheden t.a.v. onder. zoek en ontwikkeling en op de verwachte ontwikkeling van de vennootschap. Wetsontwerp 16326 ter aanpassing van de Nederlandse wetgeving aan de vierde richtlijn specificeert enkele posten waarover zulke prospektieve informatie moet worden verstrekt. Ook daarbij staat de personeelsbezetting ge. noemd.

Ten slotte moet het werk van de Group of Experts on International Stan. dards of Accounting and Reporting van de Verenigde Naties worden vermeld. Hun rapport van 18 oktober 1977 geeft vrij veel aandacht aan ,non-financial reporting”. Deze term werd algemeen toepasbaar geacht op ,all those areas not usually covered in financial statements". Onderscheid wordt gemaakt tus. sen de transnationale onderneming als geheel en de afzonderlijke ondernemingen, die daar deel van uitmaken. De lijst van elementen, waarover ten minste informatie moet worden verschaft, is op het laatste, nationale niveau gedetailleerder. Dit omdat sommige informatie bij verdere aggregatie aan be tekenis zou verliezen. Welke elementen in deze standaarden worden genoemd, staat vermeld in tabel 1. In 1980 is een Ad Hoc Intergovernmental Working Group of Experts on International Standards of Accounting and Re. porting in het kader van de Verenigde Naties aan de slag gegaan. Naar ik heb begrepen, werd één der eerste diskussiepunten gevormd door de vraag of het besproken rapport uit 1977 als basisstuk van deze werkgroep zou moeten dienen. Vooralsnog heeft dit rapport nog geen officiële status. ${ }^{3}$ )

Welke invloed hebben deze richtlijnen en standaarden nu uitgeoefend? Hierover kunnen enige indikaties worden ontleend aan het onderzoek van Lafferty en Cairns (1980). Zij hebben aan veertien ondernemingen uit verschil. lende landen onder meer de vraag gesteld van welke zijde men beïnvloed was bij het opstellen van het jaarverslag. De meeste Europese ondernemingen onderkennen een (toekomstige) invloed van de EG-richtlijnen en voorstellen; voor de overige ondernemingen zijn deze grotendeels irrelevant. De OESO richtlijnen worden door twee (Bayer en Philips) van de veertien ondernemin. gen genoemd; drie andere ondernemingen vermelden dat hun jaarverslag beantwoordt aan deze richtlijnen. De VN-standaarden worden door geen enkele onderneming gezien als van invloed op het jaarverslag. Volgens Lafferty en Cairns (1980, p. 12) is het algemene beeld dat uit hun onderzoek oprijst dat „... in this important area (non-financial statement disclosure, H.S.) there is a considerable lack of compliance by multinationals with the OECD Disclosure Gui delines. Yet the OECD, and the $1977 \mathrm{UN}$ report, call for less information than some European companies are already publishing”.

\footnotetext{
3) Zie verder het zeer informatieve artikel van Wang (1981). Hienuit komt bijzonder duidelijk her politieke karakter van de beraadslagingen en onderhandelingsresultaten naar voren: "Since non financial information, including employment and labor, was dearest to those with a labor background, it was used as a bargaining tool to arrive at compromises over financial reporting".
} 
List of minimum items for general purpose reporting of an individual member company (including the parent company) of a group of companies comprising a transnational corporation.

1. Labour and employment

(a) Description of labour relations policy

(i) Trade union recognition

(ii) Complaints and dispute settlement mechanism and procedure

(b) Number of employees as at year end and annual average

(c) Number employed by function (professional, production etc.)

(d) Number of women employees by function

(e) Number of national employees by function

(f) Average hours worked per week

(g) Labour turnover, annual rate

(h) Absenteeism - working hours lost (number and percentage of total)

(i) Accident rates (describe basis)

(j) Description of health and safety standards

(k) Employee costs

(i) Total wages, salaries and other payments to employees (before tax)

(ii) Social expenditures paid to institutions and Government for bene fit of workers (excluding pension schemes reported in the profit and loss statement)

(iii) Summary description and cost of training programmes

2. Production

(a) Description of practices regarding acquisition of raw materials and components (indicate percentage acquired from intercompany foreign sources and percentage from all foreign sources)

(b) Indicate average annual capacity utilization in accordance with normal industrial practice

(c) Physical output by principal lines of business in accordance with normal industrial practice

(d) Description of significant new products and processes

3. Investment programme

(a) Description of announced new capital expenditure

(b) Description of main projects, including their cost, estimated additions to capacity, estimated direct effect on employment

(c) Description of announced mergers and takeovers, including their cost and estimated direct effect on employment

4. Organizational structure

(a) Names of members of board of directors and, where applicable, the supervisory board and a description of their affiliations with companies outside the group

(b) Number of owners or shareholders and, where known, the names of the principal owners or shareholders

5. Environmental measures

Description of types of major or special environmental measures carried out, together with cost data, where available 


\section{Nationale situaties}

Er is nog nauwelijks enige internationale harmonisering van de niet financiële informatieverstrekking bereikt. Dit ongetwijfeld mede omdat de aandacht hiervoor van relatief recente datum is. Daarnaast spelen juist op dit terrein sociaal-culturele verschillen waarschijnlijk een grote rol. Zo kan bijvoorbeeld worden geconstateerd dat Europese experimenten met maatschappelijke ver. slaggeving sterk werknemersgericht zijn, terwijl deze in de Verenigde Staten van Amerika georiënteerd zijn op meerdere groepen deelgenoten (vgl. Schreuder, 1980). In ieder geval rijst uit een vergelijking van nationale regels t.a.v. de niet financiële informatieverstrekking een beeld van grote diversiteit op.

Toch vertonen de nationale situaties ook gemeenschappelijke kenmerken. Eén daarvan is dat de regelgeving op dit terrein sterk versnipperd is. De regels zijn in het algemeen afkomstig van (vele) verschillende instanties, terwijl een integrerend kader ontbreekt. De informatie wordt ook sterk versnipperd ver. spreid. Vele verschillende informatiemiddelen worden voorgeschreven; slechts bij uitzondering hebben de regels betrekking op het informatiemiddel bij uitstek van de onderneming: het jaarverslag. Hierdoor ontstaan niet alleen afstemmingsproblemen tussen de diverse regels, ook hun gezamenlijk effekt is moeilijk te beoordelen. Deze situatie klemt uiteraard sterk waar het de be oordeling van de wenselijkheid van nieuwe regelgeving betreft. Een tweede gemeenschappelijk kenmerk van vele nationale situaties is echter juist dat een uitbreiding van de regelgeving kan worden geconstateerd. Daarbij worden met nieuwe regels nieuwe terreinen bestreken, terwijl daarnaast bestaande regels ook verder worden gedetailleerd.

Deze korte schets maakt al duidelijk dat hier niet gestreefd kan worden naar een integrale vergelijking van de situatie in verschillende landen. Dat zou hoog. stens op een deelgebied (sociale informatie, milieu.informatie o.i.d.) kunnen ge beuren, maar ook dan zou de toegestane ruimte waarschijnlijk te kort schieten. Daarom is hier voor een andere benadering gekozen. In de volgende para. graaf zal bij wijze van illustratie de situatie in de Verenigde Staten van Amerika worden geschetst. Dit voorbeeld is gekozen omdat daar het onderzoek naar de effekten van de regelgeving wel al op gang is gekomen. Dit onderzoek zal vervolgens worden besproken, waarna ons onderwerp afsluitend in een ruimer kader wordt geplaatst.

\section{De Verenigde Staten van Amerika}

De toename van overheidsingrijpen in de Amerikaanse economie wordt vrij algemeen in verband gebracht met het New Deal-programma waarmee Franklin D. Roosevelt in 1932 de verkiezingen won. Weliswaar werd de over. heidsgreep op het economisch leven in de jaren dertig aanmerkelijk verstevigd, en werd deze tendens nog eens versterkt door de Tweede Wereldoorlog, maar de huidige situatie is toch voor een groot deel pas na het midden van de jaren zestig gecreëerd. Enige gegevens ter illustratie. Van de 32 ,federal agencies" in 1966 was de helft na 1932 in het leven geroepen. Na 1966 werden in tien jaar tijds 21 nieuwe agencies gecreëerd. Indicatief is ook de groei van het Federal Register waarin alle federale reguleringen (en gegevens die hierop betrekking hebben) worden vastgelegd. De eerste editie van 1936 besloeg 
2.599 pagina's. In 1956 was dit opgelopen tot 10.528 pagina's en in 1966 tot 16.850. In 1978 bevatte het Federal Register 36.487 pagina's (Friedman, 1979, pp. 190-191). Enkele van de belangrijkste federale regels m.b.t. niet-financiële informatieverstrekking zullen hieronder worden aangeduid. In sommige gevallen verlangen deze regels de verstrekking van zowel financiële als niet-financiële informatie, zodat een strikte scheiding hiervan niet valt te handhaven.

Het aantal federale informatieplichten varieert per type onderneming. De "Catalog of federal paperwork requirements by industry group" vermeldt bij. voorbeeld voor ondernemingen in de veeteelt 58 informatieplichten en voor chemiebedrijven 116 . In de praktijk blijken meer rapporten te worden ver strekt, onder meer doordat aan sommige regels op vestigings- of afdelingsni. veau moet worden voldaan. Zo heeft Exxon 125 pagina's nodig om de circa 600 rapporten op te sommen die deze onderneming in 1977 aan federal agen cies toestuurde (Exxon, 1977). Daarbij waren 29 rapporten aan de Environmen. tal Protection Agency, die in 1970 werd opgericht. De regels met betrekking tot te verschaffen milieu-informatie verschillen uiteraard sterk per bedrijfstak, zodat hiervan moeilijk een algemeen overzicht kan worden gegeven. Veel van de recente wetgeving is op dit terrein gericht. Naast de periodieke informatie, die op grond van deze wetten moet worden verschaft, is het opstellen van een Environmental Impact Statement noodzakelijk bij aktiviteiten met mogelijk in grijpende milieugevolgen, waarvoor overheidsmedewerking (vergunningen, financiering etc.) is vereist. Van degenen die om zulke medewerking vragen kan een Environmental Assessment worden verlangd, waarin een voorlopige analyse van de milieugevolgen van de aktiviteit is opgenomen.

Op sociaal gebied is eveneens sprake van veel recente wetgeving. Zo werd in 1974 de Employee Retirement Income Security Act (ERISA) aangenomen. ERISA had tot doel bepaalde misstanden, die bij vrijwillige pensioenregelingen waren geconstateerd, te voorkomen. Daartoe moet informatie worden verstrekt aan het Department of Labor, de Internal Revenue Service, de Pension Benefit Guarantee Corporation en aan de pensioengerechtigden zelf. Figuur 1 beeldt de gereglementeerde informatiestromen uit.

Bij de Occupational Safety and Health Act (OSHA) van 1970 ligt de nadruk op de ondernemingsadministratie. De onderneming is verplicht een logboek bij te houden van ziekten en ongevallen tijdens het werk. Over ieder hierin opgetekend geval dient meer specifieke informatie geregistreerd te worden. Van het logboek dient binnen een maand na afloop van het kalenderjaar een samenvatting te worden gemaakt. Deze samenvatting moet minstens een maand ter inzage hangen aan de prikborden van iedere werkplaats. Deze samenvattingen worden door het Bureau of Labor Statistics jaarlijks opgevraagd bij een landelijke steekproef van 540.000 werkplaatsen.

Aan de Equal Employment Opportunity Commission dient een formulier te worden gestuurd waarop per vestiging en per soort funktie staat aangege. ven welk deel van het personeelsbestand wordt uitgemaakt door vrouwen en minderheden. Teneinde achterstanden op dit gebied weg te werken dienen ondernemingen „Affirmative Action Plans” op te stellen en toe te sturen aan het Office of Federal Contract Compliance Programs, willen zij in aanmerking komen voor federale opdrachten. Zij dienen zich er dan tevens van te verge- 


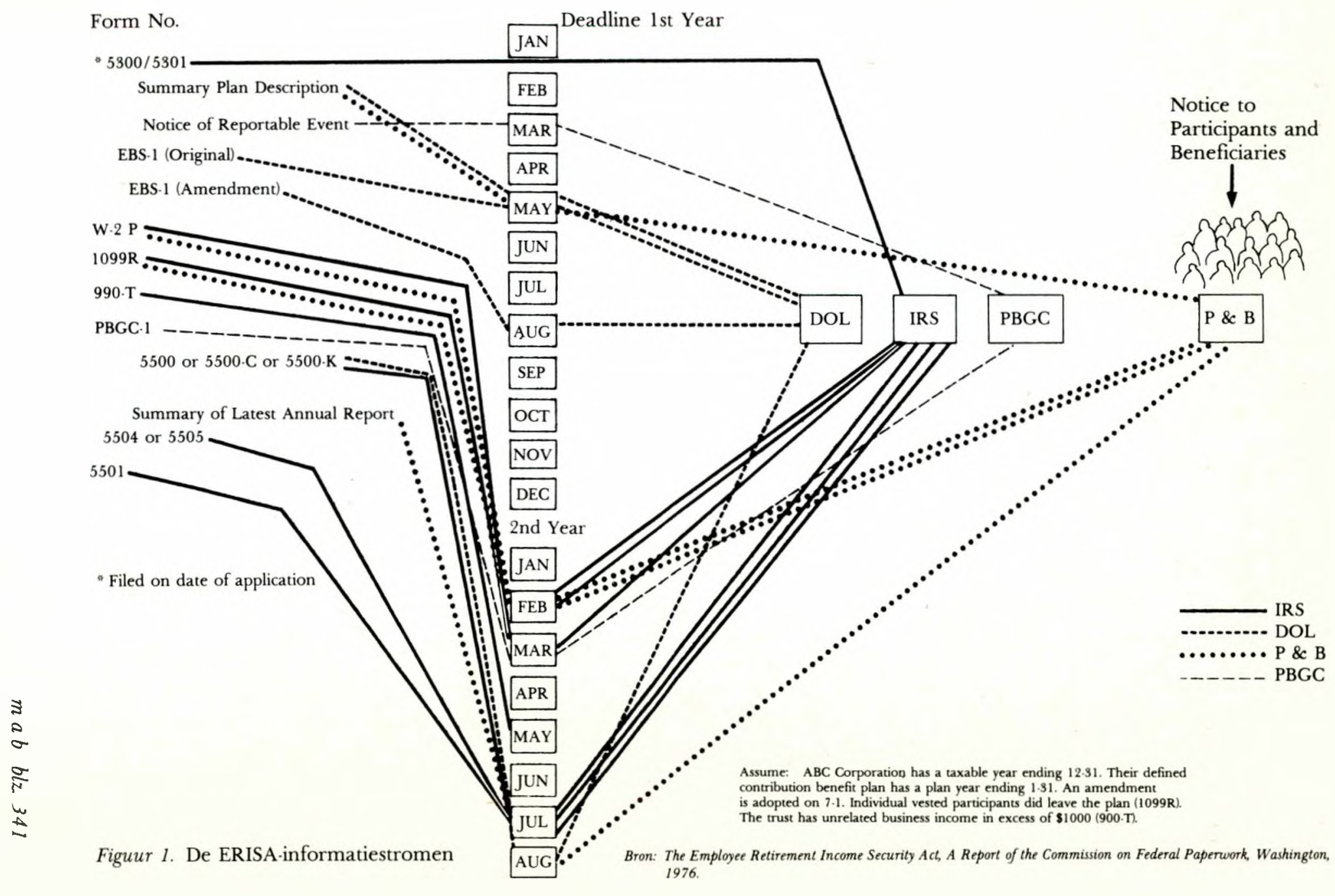


wissen dat ook hun subcontractanten aan de EEO.bepalingen voldoen. ${ }^{4}$ ) De Af. firmative Action Plans dienen een analyse van het personeelsbestand te bevat. ten naar geslacht, bevolkingsgroep en funktie; een vergelijking met lokale ge. gevens hierover; termijnen waarbinnen eventuele achterstanden zullen worden opgeheven; en een verbale aanduiding van het algemene beleid op dit ge. bied.

Een nieuw ministerie is het Department of Energy, dat in 1977 werd ge. creëerd. Hierin zijn de Federal Energy Administration en de Federal Power Commission opgegaan. Aan dit ministerie dient maandelijks te worden gerapporteerd over het brandstofverbruik van industriële vestigingen en halfjaar. lijks over energiebesparing en -verbruik. Tot slot van deze korte schets wordt nog gewezen op het „Line of Business"'rapport van de Federal Trade Commis. sion (FTC). Dit rapport werd in het leven geroepen om gesegmenteerde informatie te verzamelen bij grote, gediversificeerde ondernemingen. Hiertoe werd rechter de Standard Industrial Classification gebruikt, die niet aansluit bij de produktgroeperingen in de praktijk. Verzameling van de vereiste informatie zou derhalve zo kostbaar zijn, dat 178 van de 453 steekproefsgewijs geselekteerde ondernemingen waarvan een Line of Business-rapport werd verlangd, gerechtelijke stappen ondernamen om ontheffing te verkrijgen. De FTC ontvangt overigens ook financiële kwartaalrapporten van alle grote ondernemingen en van een steekproef uit de kleinere.

In deze paragraaf zijn geen informatieplichten vermeld, die voortvloeien uit regels van de afzonderlijke Amerikaanse staten (114 pagina's in het overzicht van Exxon, 1979) of uit contractuele verplichtingen. Dit omdat ook de gegevens in de volgende paragraaf slechts op federale regelingen betrekking heb ben. ${ }^{5}$ )

\section{Reguleringskosten}

Uiteraard zijn met de toenemende regulering kosten gemoeid. Deze nemen vele vormen aan. Een rapport van Arthur Andersen (1979) noemt bijvoorbeeld kosten als gevolg van vertragingen, produktiviteitsverliezen, afnemende investeringsbereidheid, opportunity costs etc. Dergelijke kosten werden echter buiten beschouwing gelaten bij de studie die Arthur Andersen bij 48 ondernemin. gen uitvoerde naar de direkte, additionele kosten als gevolg van regulering door zes agencies (EPA, EEO, OSHA, DOE, ERISA en FTC). Deze kosten werden gedefinieerd als "the direct costs of those actions taken to comply with a re. gulation that would not have been taken in the absence of that regulation". Aan het samenvattend rapport kan worden ontleend dat deze 48 ondernemin. gen gezamenlijk een bedrag van 2,6 miljard dollar aan dergelijke regulerings. kosten opgaven. Ter vergelijking wordt vermeld dat hun investeringen 25,8

\footnotetext{
4) De Commission on Federal Paperwork vermeldt in haar rapport over de Equal Employment Opportunity dat Kaiser Aluminium 27.000 subcontractanten moest aanschrijven om aan deze bepaling te voldoen. Ook na rappels ontving deze onderneming slechts 6.000 antwoorden.

5) Terzijde kan worden opgemerkt dat informatie berustend bij overheidsinstellingen in principe openbaar is op grond van de Freedom of Information Act uir 1966. Hierin worden negen uitzonderingen gemaakt waaronder "trade secrets and commercial or financial information obtained from a person and privileged or confidential". De jurisprudentie wijst hierbij op het criterium van concurrentienadelen. Zie verder bijv. Furby (1977).
} 
mld. dollar beliepen en hun netto winst na belasting 16,6 mld. dollar. $\left.{ }^{6}\right)$ Van deze kosten staat 42 procent gerangschikt onder „operating and administrative costs", ofwel ruim 1 mld. dollar.

Ook op landelijk niveau zijn schattingen gemaakt van de administratieve kosten van ,federal paperwork”. In figuur 2 zijn de resultaten van diverse commissies die zich hiermee in de loop der tijd hebben beziggehouden, bijeengebracht. De figuur heeft alleen betrekking op de kosten voor het bedriffsleven. Deze werden door de Commission on Federal Paperwork in 1977 geschat op 25 tot 32 mld. dollar. Hiervan nemen de 10.000 grootste ondernemingen zo'n 10 tot 12 mld. dollar voor hun rekening, hetgeen neerkomt op gemiddeld meer dan $1 \mathrm{mln}$. dollar. De circa 5 miljoen andere ondernemingen besteden gemiddeld 3.000 dollar aan federal paperwork. Gevoegd bij onder meer de kosten voor de overheid zelf en voor de burgers komen de totale kosten in deze schatting uit op meer dan 100 mld. dollar $(=500$ dollar per hoofd van de be volking). De commissie meent dat daarvan meer dan 10 mld. overbodig is en doet vele aanbevelingen om tot besparingen te komen.

Voor een deel zijn deze aanbevelingen inmiddels in praktijk gebracht, onder meer op grond van de Paperwork Reduction Act van 1980. Zo dienen de „federal agencies" nu een ,paperwork budget” in te dienen bij het Office of Management and Budget (OMB). Hierin moet het tijdsbeslag dat wordt gelegd op de respondenten, worden aangegeven. Het OMB heeft de bevoegdheid wijzigingen in dit budget aan te brengen. Voor 1981 werd 4,4 procent minder toegewezen dan was aangevraagd (OMB, 1981).

\section{Een ruimer kader}

In het voorgaande is geillustreerd dat de regelgeving op niet-financieel terrein een tendens tot (sterke) uitbreiding vertoont. Eenzelfde beeld zou geschetst kunnen worden voor vele andere westerse landen. In ons land zou dan aandacht geschonken moeten worden aan bijv. de uitbreiding van informatie plichten op grond van de WOR 1971 en 1979, de Arbeidsomstandighedenwet, emissieregistraties, de plannen tot milieu.effektrapportering e.d. In ons land is over de kosten van deze regelgeving weinig bekend. Het Amerikaanse voorbeeld laat zien dat deze kosten snel kunnen stijgen en een forse omvang kunnen aannemen. Meer fundamenteel kan op dit gebied ook sprake zijn van „overvraging van beleid" te voeren door de overheid. Niet alleen kunnen de reguleringsmechanismen zelf daardoor gaan haperen, ook de effekten van ge. nomen maatregelen kunnen tegenvallen. ${ }^{\text {) }}$

\footnotetext{
6) De industriële ondernemingen namen 2,3 miljard dollar reguleringskosten voor hun rekening (investeringen 13,4 mld., netto winst na bel. 10,2 mld.).

7) Illustratief zijn enkele bevindingen van de Commission on Federal Paperwork (1977):

- The excessive burden of the Environmental Impact Statement process arises from several factors: (1) wide variance in terminology used to express similar meaning; (2) overlapping and sometimes conflicting Federal, State and local review requirements; (3) repetitious submittal of similar or identical material to an agency.

- As a result of inconsistent or unclear compliance requirements, some companies have been forced to develop extensive and costly reporting programs which go far beyond Government mandated programs and divert resources and effort from substantive EEO gains.

- Data collected by the Equal Employment Opportunity Commission are published too late, or not at all, and are therefore not as useful as they could be...

- The need for better information on injuries and illnesses is not met by the required accumulation of logs, records and summaries.

- Substitutes for paperwork compliance with OSHA regulations should be adopted.
} 
Figuur 2. Groeicurve van de kosten van „federal paperwork”.

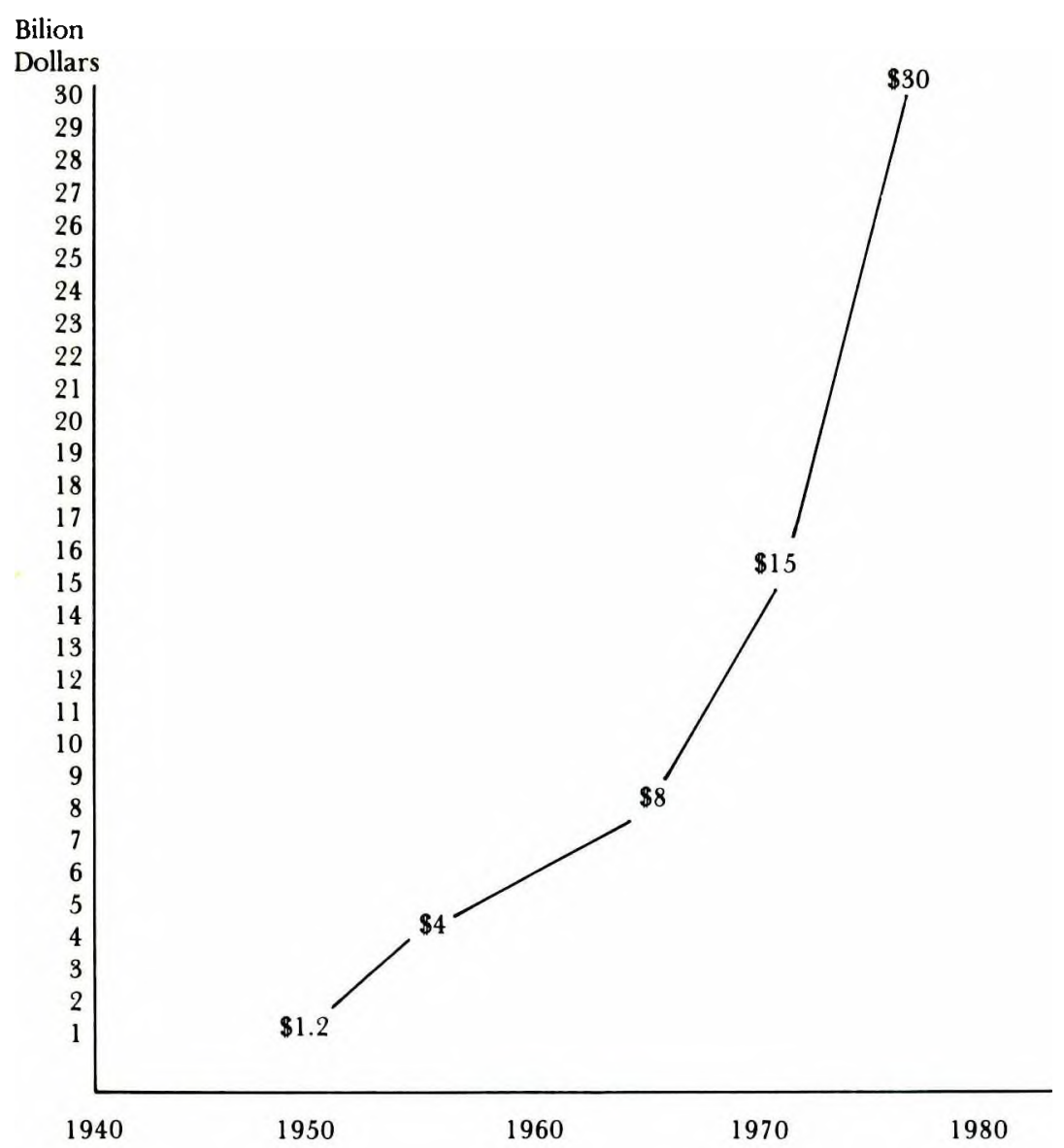

Time Frame

Sources:

First Hoover Commission - 1949

Second Hoover Commission - 1955

House Committee on Post Office and Civil Service 1965

General Accounting Office - 1972

Commission on Federal Paperwork - 1975

Bron: Buchholz (1980, p. 29). 
Er is derhalve reden de regelgeving in een ruimer kader te plaatsen. Daarbij zal hier de vraag centraal staan welke alternatieven bestaan voor de regelgeving in het algemeen en voor verplichtingen tot informatieverstrekking in het bijzonder. ${ }^{8}$ ) Voor wat betreft het algemene gedeelte van deze vraag kan worden aangeknoopt bij een analyse van Beesley en Evans (1978). Zij onderscheiden drie mechanismen ter ,regulering" van sociale groepen, t.w. de markt, de politieke keuze en de individuele verantwoordelijkheid. Beesley en Evans (1978, p. 30) constateren dan dat vanuit de feilen van de markt vaak rechtstreeks geconcludeerd wordt tot de noodzaak van politieke regulering. Op deze wijze vindt een verdringing van marktkeuzen door politieke keuzen plaats. Ook ten aanzien van zich nieuw aandienende terreinen van maatschappelijke „re. gulering" wordt in toenemende mate eerst gedacht aan politieke oplossingen. Op deze wijze raakt het politieke kanaal overbelast.

Een aantal auteurs, waaronder in de eerste plaats Friedman, bepleit een her. overweging van de mogelijkheden van het marktmechanisme, teneinde de geconstateerde tendensen terug te dringen. Ten dele is dit ook op gang gekomen, bijvoorbeeld in het onderzoek naar de economische funktie van ,eigendomsrechten" in het maatschappelijk bestel. Door de toekenning van eigendomsrechten kan immers een markt worden gecreëerd. Op grond van dergelijke rechten kan het gedrag van anderen worden beïnvloed, met alle economische consequenties van dien. Ook degenen die heroverweging van de mogelijkheden van de markt bepleiten, betrekken echter veelal het derde genoemde reguleringsmechanisme - dat van de individuele verantwoordelijk. heid - niet in de beschouwingen.

Alle drie genoemde mechanismen berusten op de vigerende normen en waarden in de maatschappij. Wordt aan deze normen en waarden door mid. del van één mechanisme voldaan, dan kan de druk op de andere dienovereenkomstig afnemen. Met Beesley en Evans (1978) ben ik derhalve van mening dat ook dit derde mechanisme in de afweging van de algemene alternatieven moet worden betrokken (zie verder Schreuder, 1981). Het is daarbij van belang te onderkennen dat noch de eigendomsrechten noch de verantwoordelijkheden wettelijk verankerd behoeven te zijn. $\mathrm{Zij}$ dienen echter in voldoende ruime kring als legitiem te worden erkend. De wetgeving kan dan eventueel een codificerende rol spelen.

Maar ook indien politieke keuzen moeten worden genomen, bestaan vele alternatieven voor uitgebreider informatieplichten. Daartoe behoren onder meer:

- direkte ge. en verboden, te stellen door de overheid;

- marktcorrecties in de vorm van belastingen en subsidies;

- voorwaarden te stellen bij het verlenen van vergunningen, het verwerven van overheidsopdrachten e.d.;

- wettelijke regelingen inzake belangenvertegenwoordiging en/of een consultatieplicht.

\footnotetext{
8) In het verlengde daarvan ligt de vraag welke alternatieven in welke omstandigheden dienen te worden toegepast. Daar. aan komen wij hier niet toe. Zie voor enkele beschouwingen Beesley \& Evans (1978).
} 
In het algemeen vormen dergelijke maatregelen een direktere ingreep in de besluitvorming van ondernemingen dan een informatieverplichting. Ook informatieplichten beogen vaak een gedragsbeïnvloeding. Dit oogmerk wordt dan echter op meer indirekte wijze nagestreefd, nl. via het corrigerende effekt dat openheid op zichzelf kan hebben én de daaraan verbonden mogelijkheid van anderen om een beleid te voeren gericht op beïnvloeding van het ondernemingsgedrag. Daarnaast worden informatieplichten uiteraard ook ge creëerd als pendant van meer direkte maatregelen.

Wordt uit de opgesomde mogelijkheden gekozen voor verdere informatie. plichten, dan bestaan ten slotte bij de uitwerking van deze keuze nog vele mo. gelijkheden. Vele van de beschouwingen op dit gebied gaan er impliciet van uit dat de nieuwe verplichting alleen gegoten kan worden in de vorm van een „spontane informatieplicht". Arendsen de Wolff (1976, p. 57) begrijpt daaron. der "de verplichting van de onderneming op een bepaald ogenblik uit eigen beweging concreet aangegeven informatie te verstrekken". In een aantal ge vallen zal echter met een antwoordplicht kunnen worden volstaan, nl. de ver plichting om op verzoek bepaalde aangegeven informatie te verstrekken. Een antwoordplicht kan de hoeveelheid in eerste instantie spontaan te verstrekken informatie beperken. ${ }^{9}$ ) Bij de verdere uitwerking van spontane informatie. plichten dienen nadere keuzen te worden gedaan met betrekking tot inhoud en vorm van de informatie, de wijze van verspreiding en het verspreidingsge. bied. Deze keuzen zijn voor een deel interdependent.

Aan alle keuzen zijn voor- en nadelen verbonden, vanuit de economische optiek kosten en baten. De in het voorgaande aangeduide reguleringskosten maken nog maar een beperkt gedeelte uit van de benodigde kostengegevens voor een goede onderlinge afweging van de alternatieven. De baten zijn nog moeilijker vast te stellen. Aangezien m.i. voorlopig niet valt te verwachten dat de bron waaruit de druk tot verdergaande informatieverstrekking voortkomt (zie par. 2), spoedig zal opdrogen, is onderzoek naar de benodigde gegevens voor een verantwoorde keuze uit de geschetste alternatieven dringend noodzakelijk.

\section{Slot}

In het voorgaande kon geen vergelijking worden gemaakt van de regelgeving ten aanzien van de niet-financiële informatie in verschillende landen. De re. denen daarvoor zijn in paragraaf 4 uiteengezet. De situatie in de Verenigde Sta. ten is bij wijze van voorbeeld geschetst, aangezien daaromtrent ook enige ge. gevens beschikbaar waren m.b.t. de effekten van deze regelgeving. Dergelijke gegevens ontbreken in vele andere landen, waaronder het onze. De indruk be staat echter dat de gesignaleerde toename van informatieplichten op niet.fi. nancieel terrein en ook de versnippering als gevolg van het optreden van vele verschillende instanties kenmerkend zijn voor vele nationale ontwikkelingen in de westerse wereld.

\footnotetext{
9) Arendsen de Wolf(1976, pp. 67.68) bespreekt de antwoordplicht alleen als aanvulling op de spontane informatieplicht. Hier worden beide ook als deels onderling verwisselbar beschouwd.
} 
Nu kunnen uit de geschetste tendensen op zichzelf weinig conclusies worden getrokken omtrent de wenselijkheid van een dergelijke ontwikkeling. Dit artikel dient dan ook allerminst te worden opgevat als een pleidooi tegen dergelijke regelgeving. Wel is er hier de aandacht op gevestigd dat in vele gevallen alleen al de feitelijke informatie ontbreekt om een oordeel op te baseren. Daartoe behoort informatie over de omvang en de verdeling van de kosten van re. gelgeving alsmede over de effektiviteit van de regels. Zulke gegevens ontbreken al over afzonderlijke regels, terwijl voor een afweging van de in paragraaf 7 genoemde alternatieven eigenlijk zelfs een geïntegreerd kader aanwezig zou moeten zijn. Binnen een dergelijk kader zou een antwoord moeten kunnen worden gevonden op de vraag welk alternatief onder welke omstandigheden het meest in aanmerking komt, gegeven bepaalde doelstellingen. ${ }^{10}$ ) Ontbreekt een geïntegreerd kader, dan kan de nadruk te zeer komen te liggen op bepaal. de (soorten) alternatieven.

Deze situatie klemt te meer, indien de verwachting wordt onderschreven dat de druk tot nationale en internationale regelgeving op dit terrein zal voortduren (vgl. par. 2), de internationale regels meer een bindend karakter zullen krijgen, en de harmonisering van deze regelgeving niet soepeler zal verlopen dan op financieel gebied. Ik ben benieuwd hoe de aandacht voor de financiële en de niet-financiële informatie verdeeld zal zijn, wanneer de M.A.B.-redaktie over enkele jaren besluit weer een bijzonder nummer te wijden aan de regel. geving ten aanzien van de ondernemingsberichtgeving.

\footnotetext{
10) Eén van de auteurs bij wie al aanzetten tot een dergelijk kader zijn te vinden, merkt terecht op: „For certain purposes it is clear that regulation is best, but it is equally clear that it is not useful as a universal device" (Arrow, 1973, p. 311).
} 


\section{Literatuur}

Arendsen de Wolff, G. J. W., De informatieplicht van de onderneming Deventer, Kluwer, 1976.

Arrow, K. J., Social responsibility and economic efficiency, Public Policy, vol. 21, 1973, pp. 303-317.

Arthur Andersen and Co., Cost of government regulation study, Prepared for the Business Roundtable, 1979.

Beesley, M. E. en T. Evans, Corporate Social Responsibility, London, Croom Helm, 1978.

Blanpain, R., Richtlijnen voor multinationale ondernemingen, Alphen a.d. Rijn, Samsom, 1980.

Bouma, J. L. en J. H. R. van de Poel, Vermaatschappelijking van de onderneming, Maandblad voor Accountancy en Bedriffshuishoudkunde, jrg. 53, no. 8/9, 1979, pp. 346-354.

Brevoord, C., Externe informatievoorziening: naar een jaarbericht-nieuwe-stijl, Economisch Statistische Berichten, jrg. 63, nr. 3181,1978 , pp. 1184.1190.

Buchholz, R. A., Corporate costs for compliance with government regulation of information, in: A. R. Abdel. Khalik, Government regulation of accounting and information, Gainesville, University Press of Florida, 1980

Commission on Federal Paperwork, Final Summary Report, Washington, US Government Printing Office, 1977.

Dijck, J. J J. van, Vermaatschappelijhing van organisaites, oratie Tilburg, Leiden, Stenferc Kroese, 1975.

Exxon Company U.S.A., Reports submitted to federal agencies, state agencies, trade associations and other organizations, Houston, Exxon, 1977.

Friedman, M. en R., Free to choose, New York, Harcourt Brace Jovanovich, 1979.

Furby, T. E., The Freedom of Information Act: Survey of litigation under the exemptions, Mississippi Law Jou rnal, vol. 48, 1977, pp. 784.817.

Koopman, C. A., De onderneming en de economische orde, Maandblad voor Accountancy en Bedriffshuishoudkunde, jrg. 53, no. 8/9, 1979, pp. 364-376

Lafferty, M. en D. Cairns, Financial Times World Survey of Annual Reports 1980, London, Financial Times Business Information, 1980.

Office of Management and Budget, Information Collection Budget of the U.S. Government, Fiscal Year 1981, Washington, 1981.

Schreuder, H., Enkele ontwikkelingen met betrekking tot de sociale en maatschappelijke verslaggeving in het buitenland, in: H. J. G. Verhallen, Het sociaal verslag: feiten en meningen, Alphen a.d. Rijn, Samsom, 1980.

Schreuder, H., Maatschappelijke verantwoordelijkheid en maatschappeligke berichtgeving van ondernemingen, Leiden, Stenfert Kroese, 1981.

U.S. Small Business Administration, Catalog of federal paperwork requirements by industry group, Washington, US Government Printing Office, 1979.

Wang, N. T., Non.financial information in annual reports, Maandblad voor Accountancy en Bedriffsuishoud kunde, jrg. 55, nr. 4, 1981, pp. 194.204. 